\title{
屋根雪滑落による屋根莫材の摩耗現象に関する研究 ABRASION DAMAGE TO ROOFING MATERIALS DUE
TO SLIDING SNOW
}

\author{
伊 東 敏 幸*, 苫米地 司**, 三 橋 博三*** \\ Toshiyuki ITO, Tsukasa TOMABECHI and Hirozo MIHASHI
}

\begin{abstract}
This paper deals with abrasion damage to roofing materials caused by sliding snow on sloped roofs in a region receiving heavy snow. We tested abrasion of coated metal sheets due to sliding snow. From the test results, it became clear that three factors, namely the ratio of clay dust in roof snow, the snow load, and the snow sliding velocity, exert great influence on the abrasion. We calculated the number of times snow slid off the roof eaves for the purpose of estimating the degree of abrasion after the lapse of a certain number of years. The calculation was based on meteorological data as well as on observations of snow sliding off test roofs. From the facts described above, we obtained an equation for estimating abrasion of roofing materials of sloped roofs.
\end{abstract}

Keywords: roofing material, snow on roof, abrasion damage, sliding-snow property, mechanism of deterioration

屋根葺材, 屋根雪, 摩耗損傷, 滑雪性状, 劣化機構

\section{1.はじめに}

多雪地域においても通年利用が可能な運動施設などの 大規模構造物が本格的に建設されるようになり，それら の建築物における屋根上積雪荷重の評価および屋根雪処 理方法の確立が望まれている。一般に，大規模構造物の 屋根形状は勾配を持つ場合が多いことから, 屋根雪を滑 雪させて処理することが有効となる。1993年に改訂され た日本建築学会荷重指針においても，融雪滑雪などによ・ って屋根上積雪荷重を制御する考え方が取り入れられて

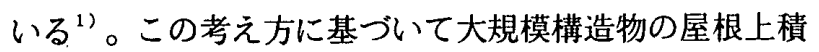
雪荷重を滑雪処理によって制御することを考えると, 一 定の積雪深以下で規則的に滑雪現象を発生させる必要が あり，さらにこの滑雪現象を長期間にわたって維持しな ければならない。この滑雪処理の規則性を維持するには， 建筑物の経年に伴う屋根莫材の滑雪性能変化を把握しな ければならない。その際，滑雪性能は屋根莫材の表面性 状に大きく支配されることから, 材料表面の経年劣化後 の性状およびその劣化機構を検討する必要がある。
屋根雪の滑雪処理に関する既往の研究の多くは，未使 用状態の屋根苦材を対象として屋根雪との凍着性状ある いは摩摖性状に対する屋根莫材の表面特性や屋根雪状態 の影響を検討している ${ }^{2 \sim 5)}$ 。しかし，屋根葷材の経年劣 化後における滑雪性状に関する研究 ${ }^{8 \sim 8)}$ で指摘されてい るように，大気暴露後あるいは実際に使用されていた屋 根莫材は，劣化以前と大きく異なる滑雪特性を示す。さ らに，屋根雪を滑落処理する屋根（以下，落雪屋根とい う）に用いる塗装鋼板の劣化に関する研究 ${ }^{9}$ によると, 数年間使用された塗装鋼板表面は，屋根雪の滑雪による 摩耗（以下，滑雪摩耗という）を受け，軒先に近い部位 ほど塗膜厚が薄くなることを指摘している。落雪屋根に 用いる塗装鋼板の塗膜は下地鋼板の防錆機能と共に, 他 材料よりも優れた滑雪性 ${ }^{4,5)}$ を維持するという機能を併 せ持つものである。従って, 材料表面の塗膜が滑雪摩耗 すると， 屋根雪の滑雪性状に大きな影響を及ぼす になる。特に, この滑雪摩耗現象は屋根長さの長い大規 模構造物の場合に顕著な影響を及ぼすと考えられる。
* 北海道工業大学建築工学科 助手

** 北海道工業大学建築工学科 教授. 工博

*** 東北大学工学部建築学科 教授. 工博
Research Assoc., Dept. of Architecture, Hokkaido Institute of Technology

Prof., Dept. of Architecture, Hokkaido Institute of Technology, Dr. Eng.

Prof., Dept. of Architecture, Faculty of Engineering, Tohoku Univ., Dr. Eng. 
屋根萝材の経年劣化に関しては, 大気暴露による一般 劣化すなおち紫外線, 大気污染物質および雨水などに対 する材料の耐久性に関する研究 ${ }^{10-12)}$ が行われ, 劣化要 因と劣化機構について検討されている。しかしこれら の研究では滑雪摩耗による材料多化を検討していない。 さらに, 各種材料の摩擦および摩耗に関する研究 ${ }^{13.14)}$ においても，雪水体との摩擦で生じる材料表面の摩耗に 関する考察は行われていない。

以上のような背景から, 本研究は屋根㯰材の滑雪性能 を維持するという観点から，その材料劣化に関する基整 資料を得ることを目的とし，塗装鋼板を対象とした滑雪 摩耗促進試験を行い，その結果と気象デー夕に基づいて 算出した屋根雪の落雪量を用いて滑雪摩耗量の経年変化 を推定した。

\section{2. 研究の方法}

本研究では, 落雪屋根の屋根惪材における滑雪摩耗量 の経年変化を推定するため次のことを行った。

1)屋根荤材の滑雪摩耗に及ぼす滑雪時の諸要因の影䋅を 定量的に評価するため，塗装鋼板を対象とした滑雪摩 耗促進試験を行った。

2)試験建物を設置し，その屋根における落雪状況の観察 から，落雪を引き起こす気象条件について検討した。 さらに，この気象条件と過去の気象データとを照合す ることにより，札幌市などの年間落雪回数を積雪深別 に算出した。

3)上記の落雪回数を用いて滑雪摩耗量の経年変化を推定 し，実際の建築物で使用されていた塗装鋼板（以下， 実使用材という）の塗膜厚と比較した。さらにその結 果から，滑雪を受ける屋根莫材の表面务化機構を考察 した。

4)各地域における滑雪摩耗量を推定するために, 北海道 内各地の落雪回数を算出した。また, 各種屋根苦材に おける滑雪摩耗量を推定するために，材料の落砂摩耗。 試験を行った。そして，地域性と材料特性を考虑した 滑雪摩耗量の推定手法を検討した。

\section{3. 塗装鋼板の滑雪摩耗促進試験}

\section{3-1. 実験方法}

塗装鋼板を対象とした滑雪摩耗促進試験を次のように 行った。滑雪摩耗に及ぼす滑雪時の諸要因は, 屋根の滑 雪長さ增加に伴う摩耗量変化, 滑雪面に介在する砂塵量 の影響，滑雪時における屋根雪の速度および荷重の影響 が考えられることから，これらの要因を変化させた実験 を行った。実験は写真 1 に示すような滑雪摩耗試験装置 を用いて、 $-1^{\circ} \mathrm{C} の$ 恒温室内で行った。実験に供した試料 は多雪地域の屋根覀材として一般的であり, かつ後述す る実使用材と同一材料である塗装溶融严鈆めっき鋼板
(JIS G 3312)のポリエステル樹脂光沢仕上げとした。塗 装鋼板の滑雪摩耗は図 1 に示すように, 試験装置に取り 付けた合板に接着した試料上で, 雪水体を回転運動させ て行った。実験に用いた雪水体は屋根雪の下層部を想定 し, ざらめ雪に粒径 $0.3 \mathrm{~mm}$ 以下の細骨材を混入させ, 砂 の含有状態が均一になるように摫拌した後， $5 \mathrm{~cm}$ 角の立 方体に整形して $-5^{\circ} \mathrm{C} て ゙$ 涷結させたものを用いた。この雪 水体に用いた雪は自然雪であり, 整形後の雪密度は 0.7 〜 $0.8 \mathrm{~g} / \mathrm{cm}^{3}$ である。滑雪時の諸要因変化を再現する方 法として, 滑雪長さは実験時間, 砂塺量は雪水体に含ま せる砂の重量比, 積雪荷重は雪水体上に載せる重り重量, 滑雪速度は回転軸の回転数を各々変化させて実験した。 なお，実験は同一条件で 2 枚の試料について行った。こ のような方法で次に示す 3 通りの実験を行った。

1)滑雪長さの増加に伴う摩耗量変化を評価するため, 滑 雪する雪水体の合計長さを $45 \mathrm{~m}$ 毎に $405 \mathrm{~m}$ まて変化させ た 9 段階の摩耗実験を行った。この実験では砂塵量を

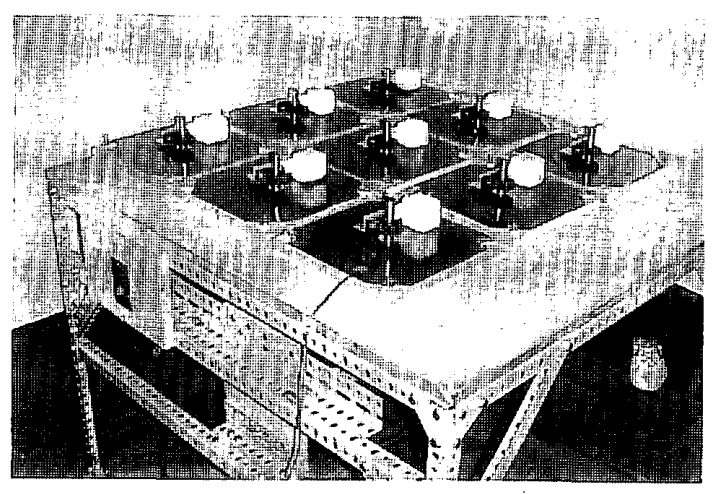

写真 1 滑雪摩耗試験に用いた装置

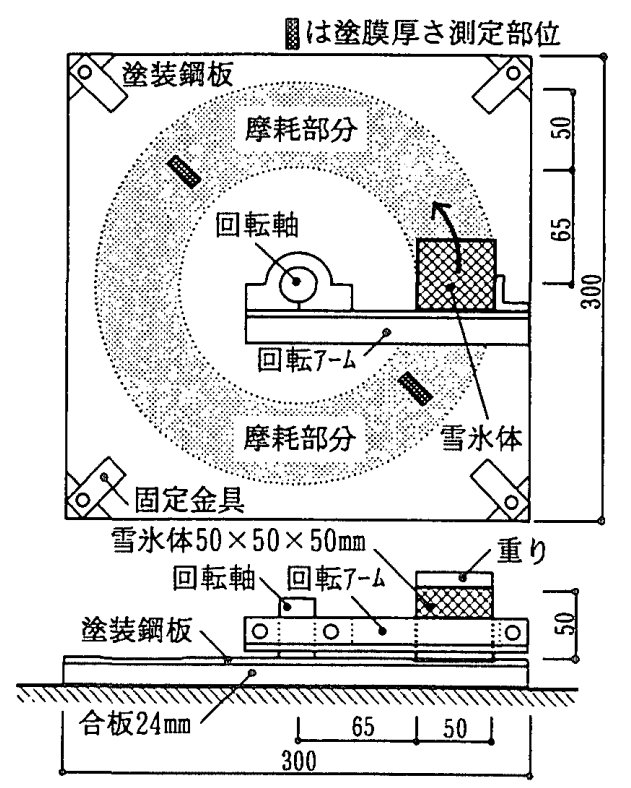

図 1 滑雪摩耗試験の方法 


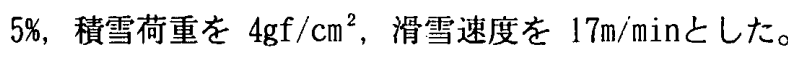
2)滑雪摩擦面の砂塵量が及ぼす影響を評価するため, 砂 塵量を $0,1,5,10 \%$ の 4 段階に変化させた実験を行っ た。この実験では滑雪速度を $8.5 \mathrm{~m} / \mathrm{min}$ ，積雪荷重を 4

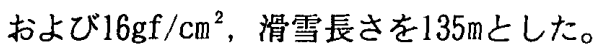

3)滑雪時の積雪荷重および速度が及ぼす影響を評価する ため, 積雪荷重を $4,8,16,32 \mathrm{gf} / \mathrm{cm}^{2}$ の 4 段階とし, 各 々において滑雪速度を 8.5,17.0,25.5,34.0m/minの 4 段階変化させた実験を行った。この実験では砂魔量を 5\%，滑雪長さを 90mとした。

滑雪摩耗試験を行った試料の摩耗量は, 摩耗部分の塗 膜厚さを測定して評価した。塗膜厚さの測定は, 図 1 に 示す摩耗部分の 2 ケ所から測定用試料（大きさ䄪 $5 \times 20$ mm）を切除して行った。切除した測定用試料の断面を耐 水ペーパーで研磨し，電子顕微鏡（1000倍）で観察した。 観察した断面から約 $1 \mathrm{~cm}$ 間隔の 2 ケ所を写真撮影し, 各 々のネガフィルムを万能投影機で拡大投影して塗膜部の 厚さを $1 / 1000 \mathrm{~mm}$ の精度で 2 点ずつ測定した。このように 測定した計 8 点の登膜厚さの平均值を摩耗前の塗膜厚さ から減じた值を塗膜摩耗厭さとした。

\section{3-2. 実験結果および考察}

塗装鋼板を対象とした滑雪摩耗促進試験の結果から， 滑雪摩耗量に及ぼす滑雪時諸要因の影響を検討する。滑 雪摩耗の進行状況を摩耗試験の滑雪長さすなわち滑雪し た雪水体長さと摩耗厚の関係からみると図 2 となる。図 のように，両者の関係は金属相互の摩耗現象にみられる 傾向 ${ }^{15)}$ 之同样に直線関係となる。滑雪摩耗を促進する 亡考えられる屋根葷材と屋根雪の摩擦面に介在する砂塵 量の影響を，雪水体に含ませた砂塵量と摩耗厚の関係か らみると図 3 となる。図に示す摩耗厚は滑雪した雪水体 の長さを $1 \mathrm{~m}$ 当たりに換算した摩耗厚である。図のように， 砂塵を混入しなかった雪水体の滑雪においても若干の摩 耗が生じ, 砂塺量が1\%になると顕著に摩耗が進行する。 なお，それ以上の砂塵量における摩耗厚は緩慢な増加傾 向となる。次に, 屋根雪の積雪荷重および滑雪速度と摩 耗厚の関係をみると図 4 亡なる。図のように, 積雪荷重 の増加に伴って摩耗厚が大きくなる傾向にあり，その傾 向は滑雪速度の増加に伴って顕著となる。

以上の結果から屋根雪の滑雪時に関わる諸要因と滑雪 摩耗量の関係について検討すると次のことが言える。滑 雪実験長さと摩耗厚が比例関係にあることから，屋根の 軒先部における屋根苦材の摩耗量は, 屋根の滑雪方向の 長さおよび屋根雪の落雪回数に比例して増加する。屋根 面上に存在する仯塵量, および屋根上積雪深に依存する 積雪荷重は摩耗量に大きく影響する。屋根葷材の摩擦係 数および屋根勾配に依存する滑雪速度は摩耗量に影響す

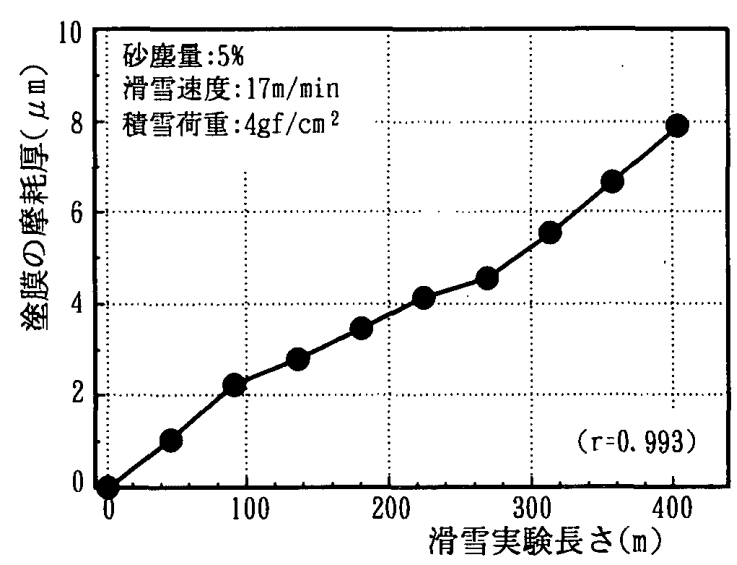

図 2 滑雪実験長さと摩耗厚の関係

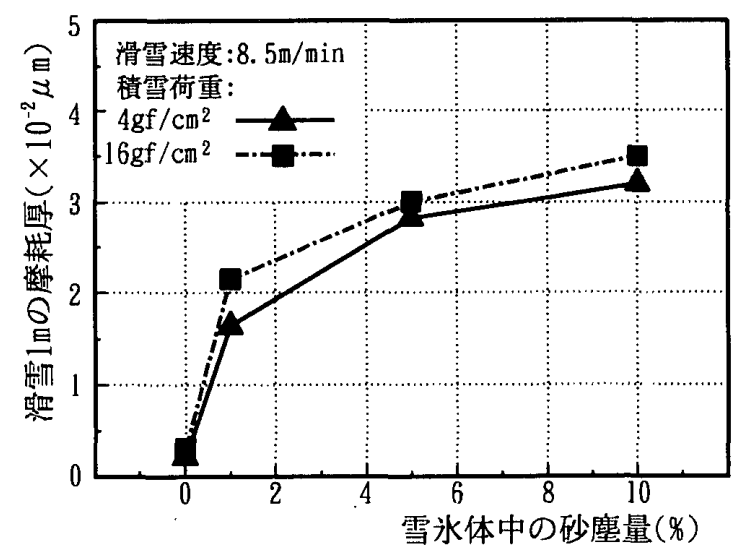

図 3 雪水体中の砂塵量と摩耗厚の関係

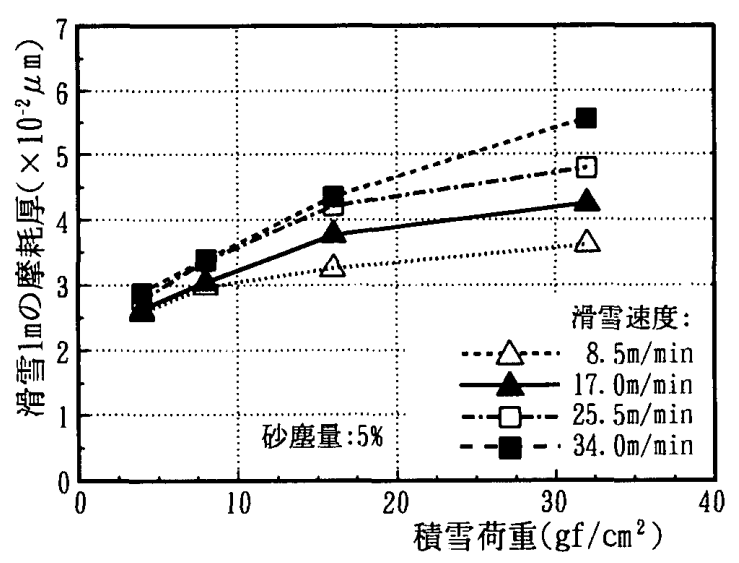

図 4 積雪荷重と摩耗厚の関係

表 1 滑雪摩耗要因間の相関

\begin{tabular}{c|c|c|c|c}
\hline 要 因 & 砂麜量 & $\begin{array}{c}\text { 楀雪 } \\
\text { 荷重 }\end{array}$ & $\begin{array}{c}\text { 滑雪 } \\
\text { 速度 }\end{array}$ & 摩耗厚 \\
\hline 砂 塵 量 & 1.000 & 0.172 & 0.441 & 0.786 \\
積雪荷重 & - & 1.000 & 0.134 & 0.601 \\
滑雪速度 & - & - & 1.000 & 0.592 \\
\hline
\end{tabular}


るが，積雪荷重が小さい場合には影響が少ない。

次に，ここで得られた実験値を用いて，滑雪摩耗量に

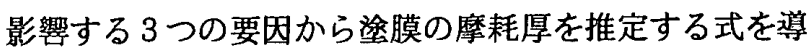
くと次のようになる。3つの要团を独立変数とし, 塗膜 の摩耗厚を従属変数として重回㷌分析を行うと次の実験 式( $r=0.95)$ が得られる。なお，ここで用いた変数間の相 関は表 1 に示すように，独立変数間の内部相関は低く， 従属変数との相関係数は約 $0.6 \sim 0.8$ である。

$$
A_{t}=(4.161 \cdot S+0.580 \cdot V+1 H+340 \cdot V-0.707) \times 10^{-3} \ldots \text { (1) }
$$

ここで， $A_{t}$ : 滑雪長さ $1 \mathrm{~m}$ 当たりの摩耗厚 $(\mu \mathrm{m}), \mathrm{S}$ : 雪水

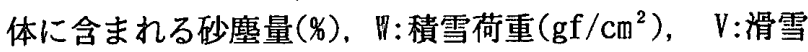
速度 $(\mathrm{m} / \mathrm{min})$ を表す。

\section{4. 屋根雪の滑雪摩耗作用の評価}

前述したように，塗装鋼板の塗膜は滑雪面の砂鹿量， 積雪荷重および滑雪速度に影殕され，滑雪長さに比例し て摩耗量が増加する。このことから, 屋根葷材の滑雪摩 耗量の経年変化を推定するには, 各地域における屋根雪 の年間落雪回数を積雪竹別に求める必要がある。

\section{4-1. 屋根雪落雪時の気象観測 \\ 1)観測方法}

滑雪摩耗量の経年変化推定に用いる積雪深別の年間落 雪回数は次のように算出した。落雪時の気象条件を定め るため, 図 5 に示すような小屋有りおよび小屋無しの試 験体を地上約 $8 \mathrm{~m} の$ 屋上に設置し, 降雪期の屋根雪状態を ビデオ撮影すると共に、試験体近傍の気象要素および屋 根部温度を観測した。小屋有り試験体は実際の小屋裏環 境を再現するため、約 $28^{\circ} \mathrm{C}$ 室内暖気を小屋裹に供給で きるようになっている。すなわち, 設置した小屋有り試 験体は天井断熱および小屋裹換気が不十分の建物を想定 し，小屋無し試験体はそれらが優れる建物を想定してい る。また，試験体の屋根は最も積雪量が多くなる ${ }^{16)}$ 勾 配(0.4) とし，その勾配において比較的容易に落雪する ように，光沢仕上げの叙装鋼板を一文字茸で苜いた ${ }^{17) 。 ~}$ 観測した気象要素は每正時における温度, 湿度, 風速, 日射量および日照時間とした。観測期間は降雪量が平年 値よりも多かった1994年の $1 \sim 2$ 月である。このような 試験体における旦根雪状態亡気象要素の観測結果から, 落雪時の気象条件を定めた。

\section{2)観測結果}

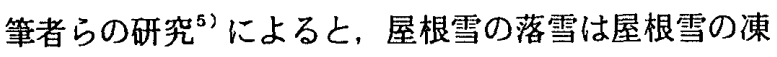
着要因すなわち屋根面温度に支配され, 屋根面温度は外 気温, 風および日射などの気象要素に依存する。このこ とから, 落雪観察用の試験体における落雪状況と屋根面 温度に影製する気象要素値を示すと表 2 になる。表に示

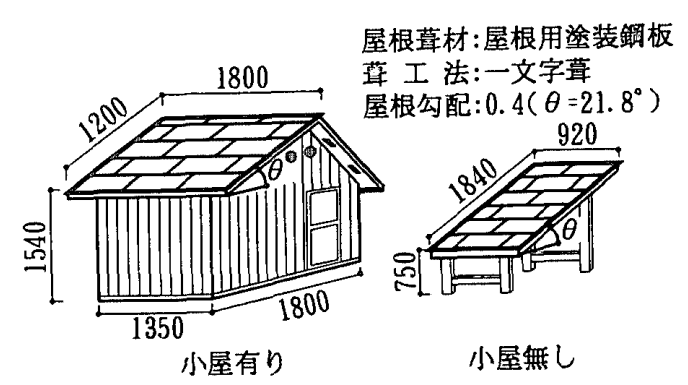

図 5 落雪観察用の試験体

表 2 屋根上積雪があった日の落雪状況

\begin{tabular}{|c|c|c|c|c|c|c|}
\hline \multirow{2}{*}{ 日付 } & \multirow{2}{*}{$\begin{array}{l}\text { 最高 } \\
\text { 気温 } \\
\left.\text { ( }{ }^{\circ} \mathrm{C}\right)\end{array}$} & \multirow{2}{*}{$\begin{array}{l}\text { 最低 } \\
\text { 気温 } \\
\left({ }^{\circ} \mathrm{C}\right)\end{array}$} & \multirow{2}{*}{$\begin{array}{l}\text { 最大 } \\
\text { 風速 } \\
(\mathrm{m} / \mathrm{s})\end{array}$} & \multirow{2}{*}{$\begin{array}{r}\text { 日照 } \\
\text { 時間 } \\
\text { (h) }\end{array}$} & \multicolumn{2}{|c|}{ ○:落雪， O：堆樍 } \\
\hline & & & & & $\begin{array}{c}\text { 小屋有 } \\
\text { 屋根 }\end{array}$ & $\begin{array}{c}\text { 小屋無 } \\
\text { 屋根 }\end{array}$ \\
\hline $1 / 19$ & -5.7 & -10.7 & 3.8 & 4.3 & 0 & (1) \\
\hline $2 / 3$ & -4.4 & -8.9 & 4.1 & 0.6 & & ? \\
\hline $2 / 4$ & -4.3 & -9.9 & 4.6 & 1.5 & 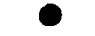 & \\
\hline $1 / 18$ & -3.9 & -10.2 & 3.3 & 2.7 & & $\theta$ \\
\hline $1 / 12$ & -3.8 & -7.4 & 2.2 & 4.0 & 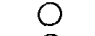 & \\
\hline $1 / 14$ & -3.1 & -17.3 & 1.8 & 4.0 & 0 & 0 \\
\hline $1 / 7$ & -2.7 & -11.8 & 7.6 & 0.0 & 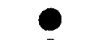 & 0 \\
\hline $2 / 10$ & -2.5 & -6.5 & $5.1^{* 1}$ & 4.9 & 0 & \\
\hline $2 / 13$ & -2.4 & -8.6 & 6.8 & 3.8 & & \\
\hline $2 / 14$ & -2.0 & -4.9 & 7.4 & 5.0 & 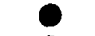 & 4 \\
\hline $2 / 2$ & -1.4 & -5.7 & 6.4 & 1.5 & 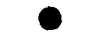 & \\
\hline $2 / 11$ & -1.3 & -6.8 & 5.0 & 3.5 & & 0 \\
\hline $1 / 20$ & -1.1 & -9.5 & 4.2 & 4.7 & & 9 \\
\hline $1 / 8$ & -0.3 & -7.5 & 2.6 & 4.6 & 0 & 0 \\
\hline $1 / 26$ & -0.3 & -6.7 & 2.3 & 5.1 & 0 & 0 \\
\hline $1 / 13$ & -0.2 & -11.8 & 2.2 & 5. 3 & 0 & 0 \\
\hline $1 / 15$ & -0.2 & -6.3 & 4.7 & 3.8 & & - \\
\hline $2 / 12$ & 0.1 & -7.0 & 2.9 & 5.1 & 0 & 0 \\
\hline $1 / 31$ & 0.7 & -15.7 & 3.2 & 5.1 & 0 & 0 \\
\hline $1 / 17$ & $1.1^{* 2}$ & -5.2 & 2.6 & 0.0 & 0 & - \\
\hline $2 / 8$ & 1.3 & -8.5 & 6.7 & 6.0 & 0 & 0 \\
\hline $1 / 16$ & 1.9 & -5.0 & 3.4 & 4.9 & 0 & 0 \\
\hline $1 / 21$ & 2.3 & -11.8 & 1.8 & 3.4 & 0 & 0 \\
\hline $2 / 17$ & 2.3 & -3.3 & 4.8 & 4.6 & 0 & 0 \\
\hline $2 / 15$ & 2.6 & -3.8 & 5.5 & 6.0 & 0 & 0 \\
\hline $2 / 5$ & 4. 1 & -4.5 & 3.4 & 5.5 & 0 & 0 \\
\hline $1 / 3$ & 4.1 & -2.0 & 3.5 & 2.9 & 0 & 0 \\
\hline $2 / 18$ & 4.4 & -3.9 & 4.4 & 7.0 & 0 & 0 \\
\hline
\end{tabular}

*1この最大風速は21:00の镍汌値。日中の很大風速は $3.3 \mathrm{~m} / \mathrm{s}$ 。 *2 この最高気温は $1: 00$ 観洲值。日中の最高気温は $-2.0^{\circ} \mathrm{C}$ 。

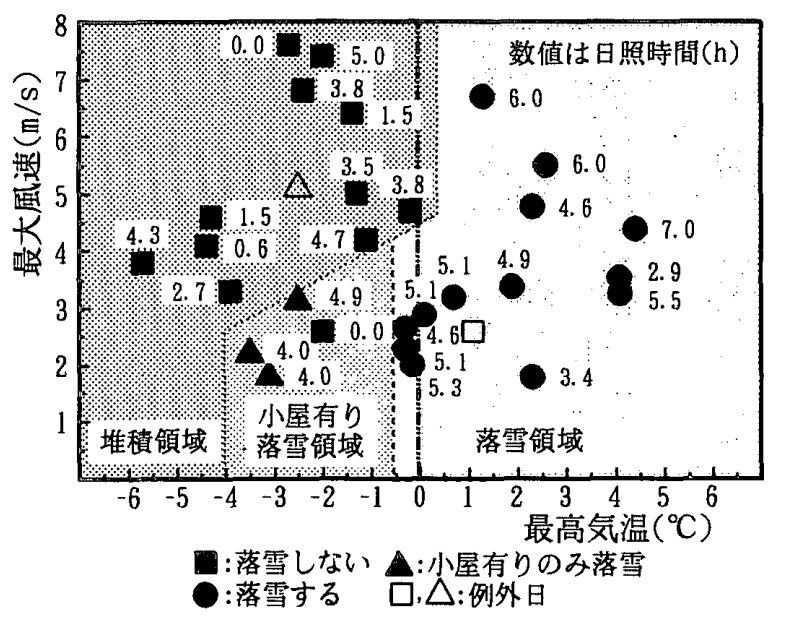

图 6 気温と風速からみた落雪状況 
す気温は毎正時に観測した温度の日最高および日最低を 示し, 最大風速は毎正時の 10 分間平均風速の日最大を示 し、日照時間は每正時に観測した值の日合計を示してい る。表のように，観測日の朝，試験体上に積雪があった 日における落雪状況は最高気温に大きく影響される。落 雪発生に大きく影響する最高気温亡最大風速の関係から 落雪状況をみると図 6 となる。図のように, 最高気温, 最大風速および日照時間でみると, 落雪しない堆積領域 小屋有りの場合に落雪する領域および小屋無しでも落雪 する領域の 3 領域に分類できる。また, 小屋有りに限り 落雪する場合には一定時間以上の日照が確認出来る。従

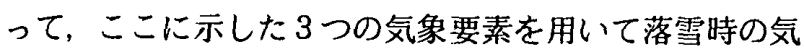
象条件を定めることが可能と考える。なお，表 2 に示し た*1および*2のような例外日もあるが，その割合は観測 期間中の $10 \%$ 以下であったことから，例外日が落雪回数 に及ぽす影響は小さいと考える。

\section{4-2. 年間落雪回数の算出}

\section{1)落雪時の屋根上積雪深の推定方法}

年間落雪回数の算出に用いた落雪時の屋根上積雪深は 次のように求めた。日本建築学会の荷重指針によると, 屋根上皘雪深は, 屋根勾配および月平均風速から求めら れる屋根形状係数に地上積雪深を乗じて推定することが 出来る ${ }^{16)}$ 。このことを基に，落雪観察用の試験体之同 じ屋根勾配におりる屋根形状係数を求め, 図 7 に示す方 法によって落雪時の屋根上皘雪深を推定した。図のよう に，屋根上積雪深は地上積雪深の前日との差である降雪 深を累積した值に, 月平均風速に基づく係数を乗じて求 めている。なお, 地上積雪深は雪の沈降や融雪によって 前日よりも減少する場合もあるが，ここで求めた屋根上 皘雪深は地上積雪深にみられる減少を考虑しないで，前 日と同じ屋根上積雪深をそのまま用いた。その理由は, 屋根上の積雪深さ範囲で生じる沈降量は微量であり,さ らに落雪しない気象条件下での屋根雪融雪量も微量と考 えられるからである。以上のように，落雪時の屋根上積 雪深を推定し, 皘雪深別の落雪回数を算出した。なお, 落雪時の屋根上積雪深が $3 \mathrm{~cm}$ 未満の場合は積雪荷重が小 さいために滑雪し難く, 落雪する条件下では融雪などに より消雪することが多いので落雪回数に算入しないこと にした。

\section{2)落雪回数の算出方法およびその結果}

各地域における年間落雪回数を算出するために用いた 過去の気象デー夕は，北海道内で積雪状況が異なる気象 官署における1981〜 1990年の10年間の気象月表および地 域気象観測積雪月原簿とした ${ }^{18)}$ 。気像月表に日毎に記 載されている気象要素は最高気温, 最低気温, 平均気温, 降水量, 日照時間, 最大風速とその風向および最深積雪 深である。なおここで，最深積雪深に限っては 9, 15,21
時の何れかに観測された不規則な観測値であることから， 落雪回数の算出に適さない。一般に, 落雪現象は昼間に 発生することが多いことから, 落雪回数の算出には朝方 に観測された積雪深が適すると考える。従って，積雪量 に関しては地域気像観測積雪月原簿に記載されている每 日朝 9 時に観測される積雪の深さを用いた。

次に, これらの気象テータから各地域の落雪回数を求 めるため，前述した落雪観察における気象条件を基に， 落雪回数が多い小屋有り試験体におりる落雪時の気像条 件を 3 つの気象要素から定めると図 8 となる。図のよう に, 落雪に対する気象要素の第一条件は最高気温, 第二 条件は最大風速，そして第三条件を日照時間亡すること によって屋根雪の落雪を判定出来る。なお，この条件に 用いた気象要素值は, 気象官署の気象表に記載されてい る值と同様に求めている。

以上のようにして定められた落雪時の気象条件と過去 の気象テータとを照合することによって，札幌における

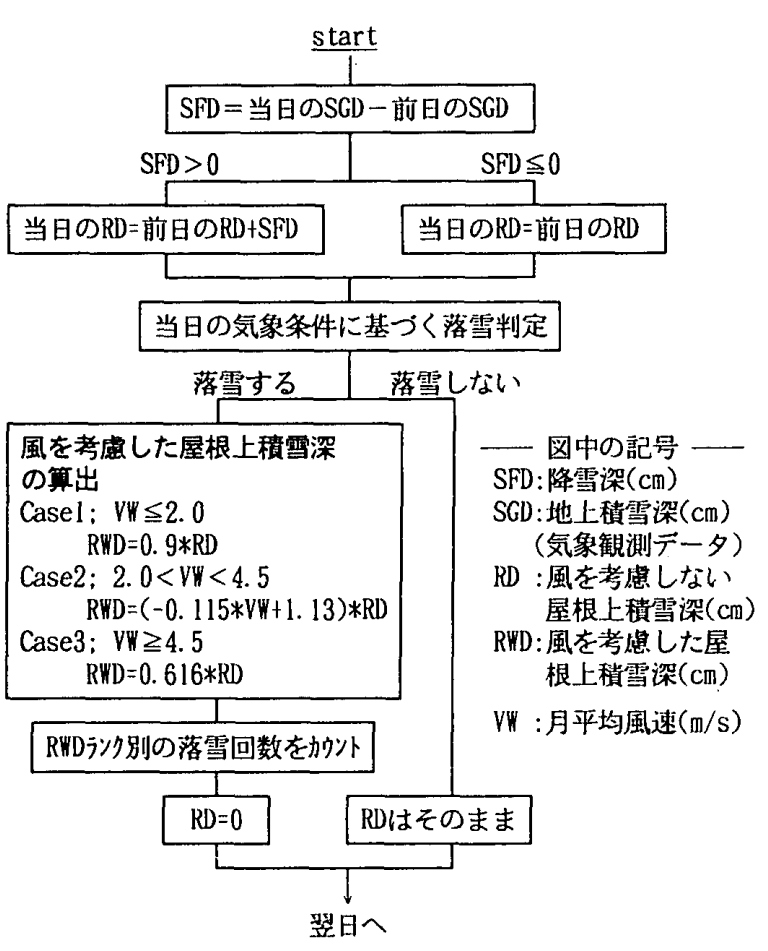

図 7 落雪時の屋根上樍雪深の計算方法

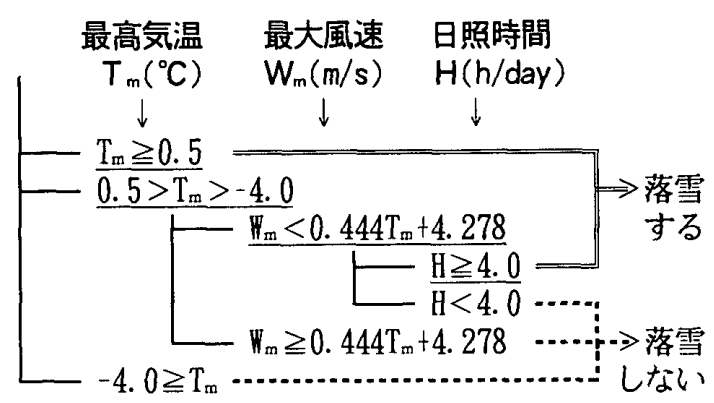

図 8 落雪回数の算出に用いた落雪時の気象条件 
年間落雪回数を屋根上積雪深別に算出すると表 3 になる。

\section{5. 屋根亘材の滑雪摩耗量の経年変化の推定}

5-1. 滑雪摩耗促進試験に基づく塗装鋼板の摩耗量推定お よび实使用屋根亘材の経年摩耗量との比較

\section{1)実使用屋根菌材の概要}

実使用材は札显市内で增改築を予定している住宅の勾 配屋根から採取した塗装鋼板であり，表 4 に示すように， 経過年数や屋根勾配の異なるものである。これらの実使 用材は傦雪摩耗の促進実験に供した材料と同じ塗装鋼板 であり，1991年に収集したものである。実使用材の塗膜 の摩耗量は, 前述の滑雪摩耗試験における塗膜厚さ測定 と同様の方法で測定している。なお，これらの実使用材 の詳細については別報 ${ }^{9)}$ を参照されたい。

\section{2)滑雪摩耗畐の経年変化推定}

過去の気象データから算出した落雪回数を用いて屋根 用叙装鋼板を対象とした滑雪摩耗量の経年変化を推定す る。滑雪摩耗量の推定は先に示した式(1) を用い，滑雪 摩耗に関わる要因である滑雪長さ, 砂塵量, 積雪荷重お よび滑雪速度の代入値は次の通りとする。滑雪長さに対

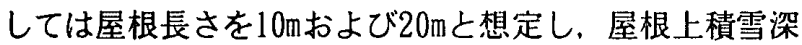
別の年間落雪回数を乗じて年間の滑雪摩耗厚を求める。 砂塵量は，札幌市の住宅地で実測した落雪後の屋根雪に おける含有砂塵量である0.1\%とし，皘雪荷重は積雪密度 を $0.2 \mathrm{~g} / \mathrm{cm}^{3}$ として求めた值を用いる。また，滑雪速度は 積雪荷重が小さい場合に摩耗量への影䇱が小さいことか ら，実使用材とほほ同様の屋根の滑雪実験から得られた 平均速度である6. $16 \mathrm{~m} / \mathrm{min}$ を一律に代入した ${ }^{19)}$ 。この ような条件で塗装鋼板の摩耗を推定すると図 9 となる。 図は塗膜厚を $20 \mu \mathrm{m}$ として求めた塗膜厚さ比の経年変化 を20年経過まで示している。また，図中には実使用材に おける塗膜厚さ比を併せて示す。次に，この図から屋根 莫材の劣化機構について検討する。

\section{3)滑雪摩耗を受ける屋根蒀材の劣化機構}

落雪屋根に用いる屋根草材の劣化は，一般外装材が受 ける大気暴露が及ぼす要因の他に，屋根雪の滑雪が及ほ す要因があることから，その劣化機構も一般外装材之異 なる。ここで, 滑雪摩耗を受ける屋根荣材の劣化機構を 先に示した図を用いて検討すると以下のようになる。図 9 に示したように, 実使用材の塗膜厚さ比は屋根長さ10 mの推定値に近い值となる。実使用材は採取部位から棟 までの長さが 4〜7mであることから，ここに示した推定 值の約 2 倍の塗膜厚減少が生じていることになる。この ことに関する他の高分子材料における実験報告 ${ }^{20)}$ があ る。それによると, 札幌市で 5 年間暴露した材料の表首 部の摩耗量を暴露前と比較すると, ポリアセタールで約 3 倍, A B S では約 4 倍になる。すなおち，高分子材料 の塗膜表層部における耐摩耗性は暴露後に著しく隇少す
る。この笁膜厚さ比の差異は次のような劧化現象によっ て生じていると考えられる。実使用材は数年間, 屋根草 材として使用されてきたので，主に夏場の影響が大きい 大気暴露による塗膜劣化亡, 降雪期に生ずる滑雪摩耗に よる㳂膜劣化を受けている。すなわち，夏場の紫外線劣 化などで脆弱化した塗膜上を, 降雪期に屋根雪が滑雪す るといった複合少化現象が年サイクルで繰り返されてい る。このような滑雪摩耗現象の発生要因を推察すると次 のようになる。一般に, 屋根雪の温度範囲における水の

表 3 気象データから算出した札幌の年間落雪回数

\begin{tabular}{|c|c|c|}
\hline $\begin{array}{c}\text { 幄根上積雪深 } \\
(\mathrm{cm})\end{array}$ & $\begin{array}{l}\text { 落雪回数 } \\
\text { (回/年) }\end{array}$ & $\begin{array}{c}\text { 年間摩耗厚 }^{*} \\
(\mu \mathrm{m} / \text { 年) }\end{array}$ \\
\hline $3 \sim 5$ & 5.2 & 0.118 \\
\hline $5 \sim 10$ & 4.2 & 0.115 \\
\hline $10 \sim 15$ & 3.2 & 0.106 \\
\hline $15 \sim 20$ & 1.6 & 0.062 \\
\hline $20 \sim 25$ & 0.9 & 0.040 \\
\hline $24 \sim 30$ & 0.2 & 0.010 \\
\hline $30 \sim 35$ & 0.2 & 0.011 \\
\hline $35 \sim 40$ & 0.4 & 0.025 \\
\hline $40 \sim 45$ & 0.2 & 0.014 \\
\hline $45 \sim 50$ & 0.2 & 0.015 \\
\hline 年合計 & 16.3 & 0.516 \\
\hline
\end{tabular}

表 4 実際に使用されていた塗装鋼板の概要

\begin{tabular}{c|c|c|c}
\hline $\begin{array}{c}\text { 試料 } \\
\text { No. }\end{array}$ & $\begin{array}{c}\text { 経過 } \\
\text { 年数 }\end{array}$ & $\begin{array}{c}\text { 勾配 } \\
(\text { deg. })\end{array}$ & $\begin{array}{c}\text { 屋根長さ } \\
(\mathrm{m})^{* 1}\end{array}$ \\
\hline $\mathrm{a}$ & 5 & 23 & 7 \\
\hline $\mathrm{b}$ & 8 & 20 & 4 \\
\hline $\mathrm{c}$ & 9 & 11 & 6 \\
\hline $\mathrm{d}$ & 13 & 10 & 5 \\
\hline $\mathrm{e}$ & 18 & 15 & 6 \\
\hline $\mathrm{f}$ & 18 & 45 & 11 \\
\hline
\end{tabular}

*1:採取部位から棟までの長さ。

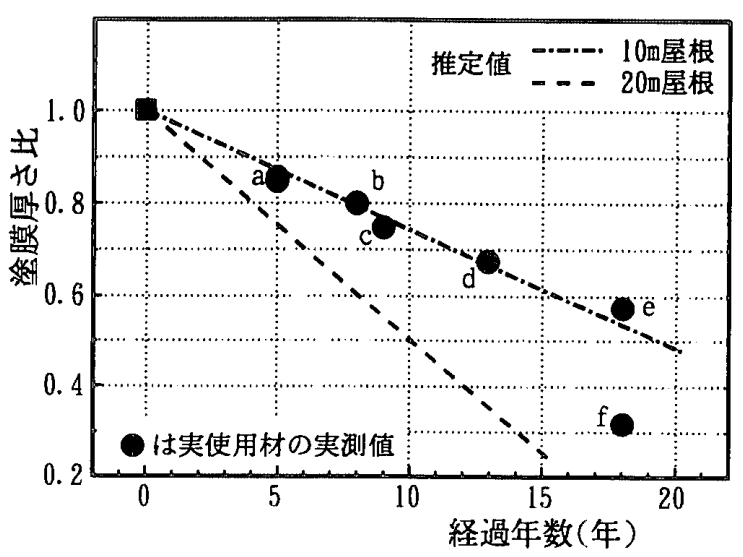

図 9 塗膜厚さの経年変化 
強度（微細な凸部のせん断強度や摩擦面の掘り起こし強 度のこと）は, 塗膜の強度よりも小さいため, 砂鹿が介 在しない状態の滑雪で叙膜が摩耗することは少ない" しかし, 実際の建築物屋根面にみられる微細な砂塵は塗 膜よりも高い強度を持つ物質であり，この砂塵が滑雪時 に研削材として作用すると叙膜か摩耗する。さらに, 紫 外線などによって樹脂分解過程にある塗膜表層部は, そ の強度が著しく低下していることから，砂鹿が介在しな い滑雪によっても容易に摩耗する。また，経年に伴う塗 膜劣化で表面凹凸が著しくなると ${ }^{9)}$, 飛来する砂塵が屋 根面に保持され易くなることから，滑雪界面の砂鹿量が 少化以前よりも増加すると考えられる。以上のように， 屋根薑材の劣化機構には一般外装材が受ける劣化要因亡 屋根雪が及ぼす劣化要因が複合して作用する。このこと が影響して, 未使用材料の推定叙膜厚さよりも実使用材 の塗膜厚さが薄くなると考えられる。

\section{5-2. 地域性および材料特性を考慮した屋根莫材の滑雪摩 耗量の推定 \\ 1)落砂摩耗試験の方法}

塗装鋼板之他の屋根荤材との機械的な摩耗状況を比較 し, その結果から滑雪摩耗量を推定するため, 各種屋根 荁材を対象とした落砂摩耗試験を行った。実験に供した 試料は表 5 に示す 7 種類の材料で，その大きさは $5 \mathrm{~cm}$ 角 とした。落砂摩耗試験は JIS A 1452 に基づく試験装置 を用いて行い，JIS R 6111に規定される「炭化けい素研 削材 $2 \mathrm{C}$, 粒度\#36」を研削材とし， その落下量を毎分 200 $\pm 10 \mathrm{~g}$ とした。各試料の摩耗量は, 実験前と 120 分経過 後の試料重量を $1 / 1000 \mathrm{~g}$ の精度で測定し, 次式によって 求めた摩耗厚 $\left(\mathrm{T}_{\mathrm{s}}\right)$ で評価した。

$$
\mathrm{T}_{\mathrm{s}}=\left(\mathbb{W}_{0}-\mathbb{W}_{1}\right) /(D \cdot A)
$$

ここで， $\mathbb{W}_{0}$ : 実験前の試料重量, $\mathbb{W}_{1}$ : 実験後の試料重量, $D$ :摩耗部の材料比重, $A$ :摩耗面積を表す。各材料の摩耗 厚は 3 回行った実験結果の平均値とした。

\section{2)北海道内における各種屋根菖材の滑雪摩耗量の推定}

登装鋼板を対象とした札幌における滑雪摩耗量の経年 変化から, 屋根葷材の劣化機構を明らかにした。それら の劣化機構を基に, 地域性および材料特性を考虑して, 落雪屋根に用いる屋根葷材の軒先部における摩耗厚 $\left(A_{y}\right)$ の経年変化を求めると，次式のように表すことが出来る。

$$
A_{y}=A_{s} \cdot \mu_{n} \cdot C_{m} \cdot C_{r} \cdot L_{f} \cdot y
$$

ここで， $A_{s}$ : 基準摩耗厚， $\mu_{\mathrm{u}}$ :紫外線劣化などによる 材料表面の脆弱度を示す係数（材料の耐候性および地域 の気候によって決まる）， $\mathrm{C}_{\mathrm{n}}$ : 各材料の摩耗抵抗度を表 す材料係数, $\mathrm{C}_{\mathrm{r}}$ : 各地域の落雪状況を示す地域係数,
$L_{f}$ : 屋根の滑雪方向の長さ, $y:$ 経過年数を表す。

この推定方法を用いて, 北海道内各地におりる滑雪摩 耗量，あるいは各種屋根荣材における滑雪摩耗量の経年 変化を推定すると以下のようになる。なお，ここでは式 （3）の $\mu_{u}$ すなわち紫外線劣化などによる材料表面の脆 弱度を示す係数は考虑しないものとする。北海道内にお いて積雪状況が異なる幾つかの地域における滑雪摩耗量 を札幌市同様に求めた落雪回数から推定し，札幌を基準 とした地域係数を求めて式(3)のC r に代入して，各地域 における塗装鋼板の塗膜厚さ比を経年推定すると図 10 と なる。各地域の摩耗量から得られた落雪状況を示す地域

\begin{tabular}{|c|c|c|c|}
\hline \multirow{2}{*}{ 試料分類 } & \multirow{2}{*}{$\begin{array}{l}\text { 試料 } \\
\text { No. }\end{array}$} & \multicolumn{2}{|c|}{ 試料概要 } \\
\hline & & 材料名 & 厚さ $(\mathrm{mm})$ \\
\hline 塗装鋼板 & $\mathrm{Cl}$ & $\begin{array}{l}\text { ポリエテテル樹脂塗装 } \\
\text { 垔鉛めっき鋼板 }\end{array}$ & $\begin{array}{l}\text { 洠膜 } 0.02 \\
\text { 材厚 } 0.40\end{array}$ \\
\hline \multirow{2}{*}{ 高分子材 } & $\mathrm{Pl}$ & アクリル板 & 0.50 \\
\hline & $\mathrm{P} 2$ & 膜材 (A 種) & 0.73 \\
\hline \multirow{3}{*}{ 金属材 } & M1 & 亜鉛板 & 0.43 \\
\hline & $M 2$ & ステンレス板 & 0.49 \\
\hline & M3 & アルミニウム板 & 0.30 \\
\hline ガラス & G1 & フロートガラス & 2.71 \\
\hline
\end{tabular}

\section{表 5 落砂試験に供した試料の概要}

表 6 落砂試験による摩耗厚さ

\begin{tabular}{c|c|c}
\hline 試料No. & 摩耗厚さ $(\mu \mathrm{m})$ & 摩耗係数 \\
\hline $\mathrm{C} 1$ & 22.8 & 1.00 \\
\hline $\mathrm{P} 1$ & 33.2 & 1.45 \\
\hline $\mathrm{P} 2$ & 14.1 & 0.62 \\
\hline $\mathrm{M} 1$ & 8.4 & 0.37 \\
\hline $\mathrm{M} 2$ & 1.6 & 0.07 \\
\hline $\mathrm{M} 3$ & 8.4 & 0.37 \\
\hline $\mathrm{G} 1$ & 59.5 & 2.61 \\
\hline
\end{tabular}

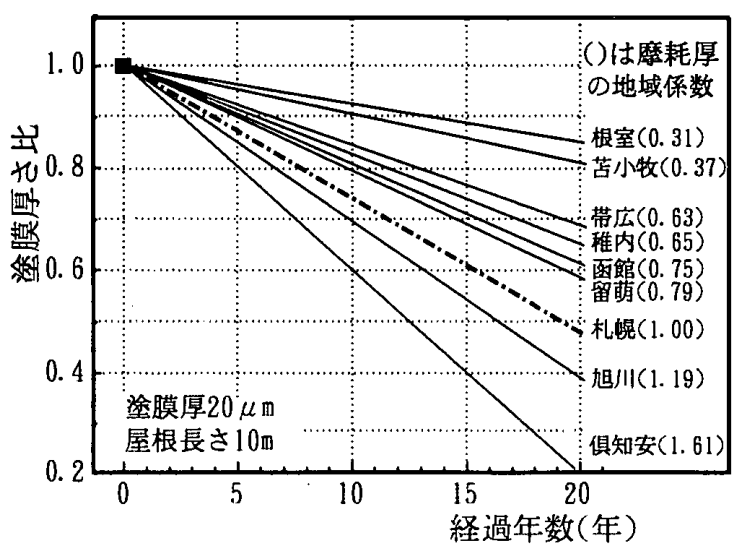

図10 北海道内における鉒膜厚さの経年変化推定 


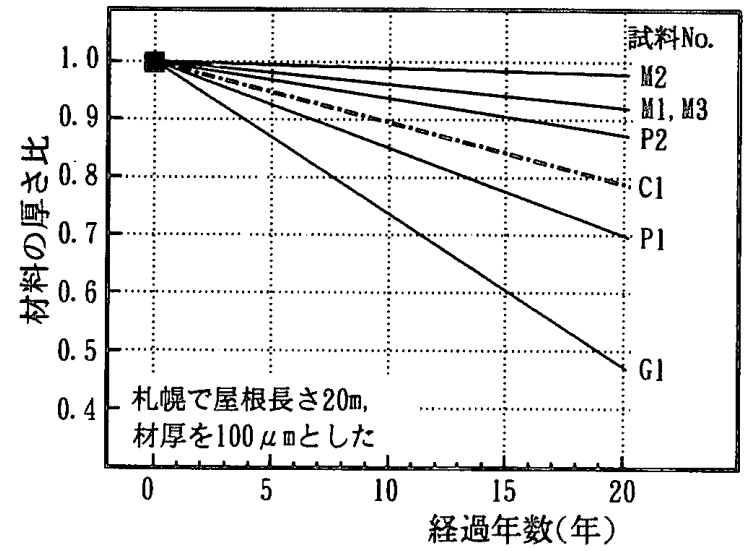

図11各種屋根菩材における塗膜厚さの経年变化推定

係数は図中に示す値である。図のように，降雪量の異な る地域における骬雪摩耗量の経年変化の羑異をみること が出来る。

次に，各種屋根惪材における滑雪摩耗量を推定する。 各種屋根蒙材の摩耗抵抗度は落砂試験の結果を係数化し て用いた。落砂実験の結果は表 6 に示す通りである。表 に示す塗装鋼板(試料 $\mathrm{C}$ ) )摩耗厚を基に係数化した摩耗 抵抗度を示す材料係数を，式(3) の $\mathrm{C}_{\mathrm{m}}$ に代入して滑雪摩 耗量の経年変化を推定すると図11となる。図のように， 金属材（試料M1，M2，M3）は登装鋼板(試料C1)よりも摩耗 が少ないのに対し，ガラス(試料G1)は摩耗量が多くなる。 また，膜材(試料P2)およびアクリル(試料P1)では塗装鉠 板と近似した摩耗量となる。

以上のような推定方法によって得られる滑雪摩耗量は, 多雪地域の落雪屋根に用いる屋根蒙材の耐久性を検討す る上で有効な指標になると考えられる。ここでは，紫外 線少化に伴う材料表面の脆弱化を示す係数を定量化でき ないが，その係数が及ぼす影響は実使用材で確認された ように極めて重要である。従って，さらに正確な滑雪摩 耗量の経年推定を行うには，その係数をに明らかにして 行く必要がある。

\section{6.まとめ}

屋根堇材の滑雪性能に影響する材料表面劣化の一要因 である滑雪摩耗現象について検討した。その結果をまと めると次のようになる。

1)登装鋼板を対象にした滑雪摩耗試験を行った結果，滑 雪摩耗量は屋根長さおよび滑雪回数に比例し，さらに 滑雪時における滑雪界面の砂塵量，積雪荷重および滑 雪速度の影響を受けることが判った。

2)屋根雪の落雪観測実験から得られた落雪時の気象条件 と過去の気象データとを照合して算出した皘雪深別の 年間落雪回数を求めた。また, この落雪回数を用いて 滑雪摩耗量の経年変化を推定する手法を示した。
3)実際に使用されていた塗装鋼板の経年劣化と摩耗量の 推定値加落雪屋根に用いる屋根荤材の劣化機構を考 察した。その結果, 落雪屋根の劣化機構には，夏場に 多い紫外線，並びに降雪期に生じる滑雪摩耗による複 合劣化作用が大きく影響していることが判った。

4)各地域の落雪状況および各種屋根苦材の摩耗抵抗度を 係数化して，落雪屋根の屋根莫材に生じる表面摩耗量 を推定する手法を提示した。

以上のことから，屋根雪を滑雪処理する建築物における 屋根莫材は，紫外線等による材料表面劣化に伴う耐摩耗 性の変化を十分に考虑したうえで，屋根雪滑雪による摩 耗特性を評価することが重要と考えられる。さらに，滑 雪による摩耗劣化を考虑して屋根葷材の耐久計画を行う 必要がある。

\section{【参考文献】}

1)日本建築学会 編：建築物荷重指針・同解説，pp. 197-200, 1993 2)前田博司 : 金属屋根におりる稭雪の滑落, 雪水, 41 巻 3 号, pp. 39 44, 1979.9

3)上野 学、高島和希, 高村久雄、福本博光：雪水に対する屋根鎆 板の特性評価，雪水，49巻3号，pp. 131-137，1987.9

4)渡辺正朋 : 屋根菆材の滑雪特性に関する基喽的研究，学位諭文 (東北大学)， 1990.6

5)伊東敏幸, 苫米地司, 三橋博三：屋根䒨材と屋根雪の凍着性状に 関する研究（材料特性と気像要素に基つく凍着過程と凍着強度） 日本建築学会構造系論文集，第470号，pp. 43-51，1995.4

6)対馬勝年 : 屋根材の麼擦に及ぼすウェザー効果，昭和58年度日本 筜水学会秋期大会講演予稿集，p，143，1983

7)伊東敏幸，苫米地司，星野政幸：劣化した屋根用塗装鋼板の表面 性状と滑雪性について，日本雪工学会誌，vol. 10，No. 2, pp. 2-10, 1994.4

8)伊東敏幸，苫米地司，星野政幸 : 少化した屋根荳材と屋根雪との 凍着性状について，第9回日本雪工学会大会論文報告集，pp. 123126, 1993.1

9)伊東敏幸，苫米地司，星野政幸：精雪地域における屋根用綮装銅 板の表面劣化に関する研究，日本建築学会構造系諭文報告集， 第444号, pp.7-12. 1993.2

10)竹島鋭機，ほか 3 名: 塗装鋼板の耐久性毒合予測法に関する研究 （第 I 報）ポリエステル樹脂系塗装銅板の酎久寿命の予測，色材， 55巻10号, pp.715-729, 1982.10

11)古谷昭夫：症膜の酎候性，防食技術，33巻 1 号, pp. 37-46, 1984.1 12)建材試験センター : 建築材料等の耐久性に関する標準化のための 調查研究報告書, pp. $34-42,1985.3$

13)F. P. Bowden and D. Tabor : The Friction and Lubrication of solids, Oxford, pp. 146-168, 1964

14)Peter J. Blau et al. : Friction, Lubrication, and Wear technology, ASH International, pp. 175-235, 1992

15)曾田籁宗 訳：固体の縻擦と潤滑，丸善，p. 271-283，1992.4

16) 日本建築学会 編：建築物荷重指針·同解説，p. 207，1993

17)伊東敏幸，苫米地司，星野政幸：屋根雪滑雪に及ぼす屋根藍工法 の影響, 日本建築学会北海道支部研究報告集、 No. 67, pp. 17-20, 1994.3

18)札㹸管区気象台：北海道気象月報，1980年4月～1990年12月

19）伊東敏幸，苫米地司，星野政幸：金属板屋根の繁工法からみた愲 雪速度特性，日本建築学会北海道支部研究報告集，No. 68，pp. 5-8, 1995. 3

20）日本規格協会 編：非金属材料データブック，pp. 24-29，1985.9 (1995年 5 月10日原稿受理, 1995年 8 月 3 日採用決定) 